\author{
Agnieszka Czyżak \\ Wydział Filologii Polskiej i Klasycznej \\ Uniwersytet im. Adama Mickiewicza w Poznaniu \\ e-mail: agnieszkaczy@tlen.pl
}

\title{
Ekocyd rekonstruowany - przeszłość i przyszłość w kronice Swietłany Aleksijewicz
}

Spuścizna Jana Jakuba Rousseau jest tworem niejednorodnym i nieraz wewnętrznie sprzecznym, zarówno na płaszczyźnie filozoficznych rozważań, jak i wyborów egzystencjalnych. Zdaniem Roberta Speamanna myśliciel „w swoim dziele i w swoim życiu po raz pierwszy wyraził paradoksy nowożytnego, nieteleologicznego pojęcia natury" ${ }^{1}$ i tym samym stał się ojcem wszelkich nowoczesnych modernizmów i antymodernizmów ${ }^{2}$. Speamann wyjaśnia:

Nieteleologiczna natura to początek, w którym nie ma żadnej wskazówki dotyczącej końca. Przyjęcie takiego początku za miarę oznacza albo ciągłą rewolucję, totalną anarchię, wszelka instytucja bowiem stanowi represję tak pojmowanej natury, albo konsekwentne i radykalne poddanie anarchicznej natury instytucjonalnym warunkom jej przetrwania ${ }^{3}$.

Nieprzypadkowo jednak Rousseau swoje rozważania na temat spornych racji istnienia $\mathrm{w}$ naturze oraz egzystencji w sferze społeczno-politycznej umieścił

1 R. Speamann, Rousseau - człowiek czy obywatel. Dylemat nowożytności, przeł. J. Merecki, Warszawa 2011, s. 11.

2 Dlatego też, zdaniem Speamannna, może być patronem: „rewolucji i restauracji, liberalnego państwa prawa i populistycznej dyktatury, przeciwnej zasadzie autorytetu pedagogiki i totalitaryzmu, romantycznego chrześcijaństwa i strukturalistycznej etnologii." Tym samym wszelkie spory o „prawdziwego Rousseau” są daremne, bowiem „dla każdej pomyłki Rousseau można znaleźć u niego odpowiednią krytykę”. I dalej: „Nowoczesna subiektywność, która znajduje w nim niezrównany wyraz, dzięki niemu też zostaje bezlitośnie zdemaskowana" [s. 11-12].

3 Tamże, s. 11. 
w kontekście pedagogicznym. W XVIII wieku natura przestała być relewantnym tłem jednostkowych inicjacji i emocji, stała się sferą negocjowania i konstruowania tożsamości indywidualnych i zbiorowych.

Zrodziło się wówczas poczucie odpowiedzialności za naturę - jej stan, kształt i przyszłość - a także wobec niej, jako dziedzictwa i daru. W latach 80. XX wieku, w ramach umacniającej się ekofilozofii zaczęły powstawać prace wskazujące na konieczność sformułowania zasad „etyki przyszłości”. Dieter Birnbacher w rozprawie z 1988 roku zatytułowanej Odpowiedzialność za przyszłe pokolenia uzasadniał wage przyjęcia takiej futurologicznej perspektywy, tworząc pesymistyczną ocenę ówczesnej fazy w historii ludzkiego gatunku:

Po raz pierwszy w historii ludzkości problematyczna staje się sama przyszła egzystencja gatunkowa ludzkości. Nie można przy tym mieć na uwadze jedynie potęgi niszczącego potencjału broni jądrowej, lecz także [...] zniszczenie ludzkości przez zarazy lub niepłodność wraz z rozwojem chemicznych i biologicznych technologii oraz ich produktów ${ }^{4}$.

Lista zagrożeń, uzupełniona między innymi o możliwe skutki zwiększenia emisji tlenku węgla do atmosfery, wskazywała na niebezpieczeństwa o wymiarze globalnym. Birnbacher przekonywał, iż wiedza o ich istnieniu musi łączyć się z przyjęciem odpowiedzialności za przyszłość, każde bowiem współczesne działanie wobec natury, a także każde zaniechanie będzie musiało ostatecznie podlegać ocenie etycznej.

$\mathrm{Na}$ powstanie tak pesymistycznej diagnozy stanu środowiska naturalnego planety i pełnej obaw wizji przyszłości miały z pewnością wpływ realia lat 80. - zarówno odkrycie epidemii AIDS, jak i rabunkowy wyrąb lasów amazońskich, zasolenie delty Nilu czy katastrofa czarnobylska. Rosnąca świadomość realnej groźby zniszczenia wspólnego domu ludzkości doprowadziła do opublikowania w roku 2000 przez UNESCO Karty Ziemi, formalnie popartej przez tysiące społecznych organizacji i ekologicznych stowarzyszeń. Jej początek brzmi:

Znajdujemy się w krytycznym momencie w historii Ziemi, w chwili, kiedy ludzkość musi wybrać swoją przyszłość. W miarę tego, jak świat staje się coraz bardziej powiązany wewnętrznie i zarazem kruchy, przyszłość kryje w sobie wielkie niebezpieczeństwo i wielkie możliwości ${ }^{5}$.

${ }^{4}$ D. Birnbacher, Odpowiedzialność za przyszłe pokolenia, przeł. B. Andrzejewski, P. Jackowski, Warszawa 1999, s. 6-7.

5 UNESCO The Earth Charte, 2000 - cyt. za: A. Wierzbicka, Karta etyki globalnej w stowach uniwersalnych, "Teksty Drugie" 2015, nr 4, s. 257. 
Kolejnym etapem działań ,jednej ludzkiej rodziny i jednej Ziemskiej wspólnoty" stało się sformułowanie Karty etyki globalnej, w którą wpisano projekt wzbudzania odpowiedzialności jednostek za stan Ziemi ${ }^{6}$.

Grożący ludzkości ekocyd skłania do zmiany postrzegania jej przyszłości jako gatunku. Ekocyd, słownikowo definiowany najczęściej jako ostatnia faza całkowitego zniszczenia środowiska naturalnego - zabicia wszelkiego życia - dokonać miałby się za sprawą człowieka, istoty, która w akcie autodestrukcji unicestwi cały świat. Wizja Apokalipsy, która nadchodzi z winy samych ludzi, nakazuje już dziś przewidywać możliwe skutki teraźniejszych ingerencji w działanie globalnego ekosystemu. Powszechność przeczucia rychłego kresu nie ogranicza się przecież do proliferacji wizji końca świata w obrębie kultury masowej, ale jest stanem zbiorowej świadomości, który zmusza do ciągłego ponawiania refleksji historiozoficznych, socjologicznych i egzystencjalnych, wychylonych ku przyszłości. We wstępie do zbioru tekstów zatytułowanego Scenariusze końca Dariusz Czaja stwierdził:

Mrok końca przyprawia o zawrót głowy, ale prowokuje, by zajrzeć za jego zasłonę; koniec bywa zagrożeniem albo obietnicą, ale tak czy inaczej zawsze stanowi wyzwanie dla dyskursywnego rozumu ${ }^{7}$.

Ekokrytyka, nurt badań rozwijający się z wolna od lat 70. XX wieku, od początku ośrodkiem zainteresowania uczyniła ogląd relacyjnie funkcjonującego globalnego ekosystemu, którego częścią jest ludzkość, oraz badanie obrazów świata współdzielonego przez człowieka z wszelkimi innymi bytami. W przestrzeni kultury odnaleźć można zarówno obrazy poświadczające fundamentalną więź człowieka $\mathrm{z}$ naturą, jak i podejmujące próbę zmiany tradycyjnego postrzegania hierarchii ziemskich istnień. Anna Barcz, pisząc o utopijnym "prometeizmie ekokrytyki”, stwierdzała, iż wedle założeń tej obecnie (od przełomu tysiącleci) szybko rozwijającej się dziedziny wiedzy: „stosunek do przyrody powinien ulec zmianie, a literatura jest tym estetycznym i wyobrażeniowym laboratorium, w którego przestrzeni teoretycznej staje się to możliwe" ${ }^{8}$. Teksty literackie i dokumentarne, manifesty spisywane $\mathrm{w}$ trosce o przyszłość czy rozrachunki z przeszłością, zarówno tworzone, jak i interpretowane z perspektywy ekokrytycznej mają na celu

6 Tamże, s. 273-275.

7 D. Czaja, Figury końca. Przybliżenia, w: Scenariusze końca. Zmierzch, kres, apokalipsa, red. D. Czaja, Wołowiec 2015, s. 10.

8 A. Barcz, Realizm ekologiczny. Od ekokrytyki do zookrytyki w literaturze polskiej, Katowice 2016, s. 51. Badaczka stwierdza nawet z przekonaniem: „tylko fikcja jest w stanie dostarczyć niemożliwego w scjentystycznym i zideologizowanym świecie modelu wiedzy na przyszłość, dzięki lekturze w czasie przeszłym" [s. 15]. 
przede wszystkim przeobrażenie zbiorowej świadomości. Do tekstów szczególnie poruszających wyobraźnię i wrażliwość odbiorców oraz wpływających na zmianę oglądu relacji człowieka $\mathrm{z}$ naturą zaliczyć można $\mathrm{z}$ pewnością „kronikę ekocydu” Swietłany Aleksijewicz.

Awaria reaktora $\mathrm{w}$ elektrowni atomowej w Czarnobylu to znany na całym świecie fakt historyczny, który miał miejsce 26 kwietnia 1986 roku. Powstało wiele raportów i opracowań dotyczących skali katastrofy - w różnych zakątkach globu, pomimo informacyjnej blokady stosowanej przez władze Związku Radzieckiego, opisywano proces degradacji środowiska będący jej trwałym skutkiem. Od samego początku katastrofa wpisywana była przede wszystkim w dwa niemożliwe do uzgodnienia dyskursy. Wedle jednego z nich "awaria reaktora" miała charakter lokalny, pochłonęła "zaledwie" 31 ofiar bezpośrednich i około 200, które zapadły na chorobę popromienną, natomiast jej skutki okazały się w istocie krótkotrwałe. Dyskurs apokaliptyczny wskazywał na niepojętą skalę tragedii i jej nieusuwalne konsekwencje - nie tylko dla środowiska i mieszkańców w promieniu kilkudziesięciu kilometrów od wybuchu, ale i dla zbiorowej świadomości - w wymiarze narodowym, europejskim i światowym. Ekocyd na ziemiach Ukraińskiej i Białoruskiej Republiki ZSRR zyskał znaczenia symboliczne, zarówno w sferze politycznej, jak i kulturowej.

Szczególnie istotnym podsumowaniem „czarnobylskiego tematu” okazał się tekst z wnętrza doświadczenia, napisany jednak z czasowego dystansu wydana w 2005 roku książka Swietłany Aleksijewicz Czarnobylska modlitwa. Kronika przyszłości. Zbiór zawiera istotne elementy obu dyskursów równocześnie, co stało się możliwe za sprawą przyjętej perspektywy - wyznania świadków, których liczba bliska jest tej z oficjalnych raportów, przedstawiają wizję końca świata, co prawda z perspektywy jednostkowej, ale w wymiarze ostatecznym. Oddanie głosu ofiarom tragedii i ich rodzinom, ocalałym i naznaczonym na zawsze traumą, okazało się też wyrazistym gestem opowiedzenia się po stronie „historii mówionej” jako uprawomocnionego jednostkowym przeżyciem świadectwa doświadczeń historycznych.

Siła osobistych opowieści o śmierci, chorobie, utracie pozwala na wejrzenie $\mathrm{w}$ traumę doświadczenia, $\mathrm{z}$ drugiej jednak strony, są to pojedyncze głosy, wyrwane $\mathrm{z}$ anonimowości i osadzone $\mathrm{w}$ konkretnych realiach, co wprowadza je w sferę zwyczajności. Zbiór otwiera i zamyka Samotny głos ludzkiopowiedziane przez kobiety historie ich utraconej wielkiej miłości. Pierwsza z nich to Ludmiła Ignatienko, żona jednego ze strażaków gaszących pożar, którzy zmarli po kolei $\mathrm{w}$ jednym $\mathrm{z}$ moskiewskich szpitali przed upływem miesiąca od wybuchu. Trwającą przy mężu do końca kobietę "uratowała” od śmierci jej nienarodzona córka, która przyjęła na siebie radioaktywne 
skażenie - dziecko zostało pochowane w jednym grobie z ojcem. Ostatnią historię opowiada Walentina Timofiejewna Apanasiewicz, żona likwidatora, który jako ostatni ze swojej grupy zapadł na chorobę nowotworową i przez rok konał w męczarniach. I nadzwyczaj szybki zgon strażaka i długie, bolesne odchodzenie likwidatora ukazane zostały z perspektywy osieroconych towarzyszek życia. Co jednak znaczyłoby określenie - niemal odruchowe ich rozpaczy "zwierzęcą"? Czy tylko to, że była - jak można wyczytać z ich relacji - niepohamowana, przepełniona bezradnością, skłaniająca do irracjonalnych zachowań, a także poświadczająca niemożność zinterioryzowania i eksplikacji doświadczenia?

W książce zamieszczony został Wywiad autorki z sama sobq o historii pomijanej i o tym dlaczego Czarnobyl stawia pod znakiem zapytania nasz obraz świata, w którym pada wyrażone wprost przekonanie:

Dwie katastrofy nałożyły się na siebie: pierwsza, społeczna - na naszych oczach rozleciał się Związek Radziecki, zapadł się pod wodę gigantyczny ląd socjalizmu; druga, kosmiczna - Czarnobyl. Dwa wybuchy globalne. Pierwsza z katastrof jest bliższa, bardziej zrozumiała [...] Ale o Czarnobylu wolelibyśmy zapomnieć, bo przed nim skapitulowała nasza świadomość. To była katastrofa świadomości. Świat naszych wyobrażeń i wartości wyleciał w powietrze ${ }^{9}$.

Polityczne reperkusje awarii reaktora zdeterminowały przebieg zdarzeń historycznych, jednak istotniejsze okazały się dokonywane post factum diagnozy kondycji ludzkiej w nowej, trudnej do zaakceptowania odsłonie.

Aleksijewicz przyjęła perspektywę swoich rozmówców, stąd jednoznaczne wyznanie: „Jestem świadkiem Czarnobyla... Najważniejszego wydarzenia XX wieku, mimo że upamiętnił się on także strasznymi wojnami i rewolucją" [s. 31]. Doświadczenie okazało się najważniejsze, bo zostało uznane za specyficzne "doświadczenie graniczne" nie tylko dla jednostek, narodów, ale przede wszystkim dla ludzkiego gatunku. Autorskie działania - dobór świadectw, ich montaż, zapis sugerujący mowę z trudem wydobywaną przez ściśnięte gardło - wzmacniają siłę przekazu ${ }^{10}$. Na postawione sobie samej pytanie, "czemu daję świadectwo" w spisywanym tomie, autorka odpowiada (zgodnie z podtytułem książki), że jest to opowieść o przyszłości, o początku nowej historii.

9 S. Aleksijewicz, Czarnobylska modlitwa. Kronika przyszłości, przeł. J. Czech, Wołowiec 2012, s. 39. Dalej cytaty w tekście z numerami stron według tego wydania.

10 Podobne znaczenie ma wielokrotnie stosowany zabieg zawieszania opowieści, zaniechania zakończeń i nasuwających się wniosków - rozmówcy sugerują, by autorka/słuchaczka uczyniła to samodzielnie, a tym samym z podobnym zadaniem musi zmierzyć się odbiorca, aktywnie współtworząc opowieść. 
Już pierwsze godziny i dni po awarii pokazywały odmienność sytuacji, w której znaleźli się mieszkańcy rozległych okolic elektrowni ${ }^{11}$. Nadejście niewidocznej śmierci, niedostrzegalnej dla ludzkich zmysłów sprawiało, że ucieczka ze skażonych terenów dla wielu wydawała się decyzją niedostatecznie zrozumiałą. Przymusowa ewakuacja uniemożliwiła z kolei uratowanie zwierząt - nieprzewidzianych w planach zarządzonych odgórnie działań. Aleksijewicz wskazywała:

Co zostawało w martwej strefie po tym, jak uciekli z niej ludzie? Stare cmentarze i cmentarzyska zwierząt. Człowiek ratował tylko siebie, wszystkich innych zdradził. Po ewakuacji do wsi wkraczały oddziały żołnierzy albo ochotników i rozstrzeliwały zwierzęta. Psy uciekały na dźwięk ludzkiego głosu... I koty... Konie też nic nie rozumiały [...] Bezradne krzyki zwierząt... Krzyczały każde w swoim języku... [s. 37-38].

Skażenie objęło całą przestrzeń, wszystkie istoty - od dżdżownic próbujących zakopać się głębiej w ziemi, pszczół przyczajonych w ulach, ptaków i zwierząt domowych po człowieka. Jednak tylko człowiek mógł przewidzieć katastrofę i był za nią odpowiedzialny.

Z innych opowieści wynika natomiast, że ludzie ostatecznie zdradzili też samych siebie - przede wszystkim odsłonięta została skala obojętności wobec pojedynczych ludzkich losów, między innymi rzeszy tzw. likwidatorów zmuszanych do porządkowania obszaru zamkniętej, najbardziej skażonej strefy bez odzieży ochronnej. Zaskakująca była także nierozumna chciwość tych, którzy rozkradali skażony dobytek i rozprowadzali go nie tylko na pobliskich bazarach, ale wywozili w głąb kraju, by zarobić na mieniu porzuconym przez ofiary. $\mathrm{W}$ ostatecznym rozrachunku człowiek podzielił los wszystkich stworzeń, całej natury, którą zniszczył i skaził wybuch - stracił tym samym swoją uprzywilejowaną pozycję w hierarchii gatunków. Paradoksalnie, to katastrofa dowiodła jedności człowieka z otaczającym go światem. Ekocyd przekształcił heterotopiczną przestrzeń w jednorodne nie-miejsce: skażone, opustoszałe i odseparowane od reszty świata.

11 Katastrofa wydarzyła się za czasów istnienia Związku Radzieckiego. Obecnie elektrownia znajduje się na terytorium Ukrainy. Aleksijewicz zwraca jednak uwagę, że największe szkody wybuch reaktora przyniósł mieszkańcom Białorusi: „Awaria czarnobylska była najpotężniejszą z katastrof technologicznych XX wieku. Dla niewielkiej (10 milionów obywateli) Białorusi okazała się narodowym nieszczęściem [...] Podczas Wielkiej Wojny Narodowej hitlerowcy zniszczyli tu 619 wsi i wymordowali ich mieszkańców. Po Czarnobylu kraj stracił 485 wsi i osiedli, $70 \mathrm{z}$ nich na zawsze już zniknęło pod ziemią. Podczas wojny zginął co czwarty Białorusin, dzisiaj co piąty mieszka na terenie skażonym" [s. 7]. 
Ewa Domańska podkreślała, iż współczesna humanistyka staje się częścią procesu, który ma doprowadzić do powstania holistycznej, komplementarnej i integrującej wiedzy, natomiast wybór humanistyki ekologicznej jako preferowanej ramy interpretacyjnej czy perspektywy badawczej pozostaje wciąż wyborem światopoglądowym ${ }^{12}$. Domańska wskazywała także, iż humanistyka zmierza w kierunku utopii, której jedną z manifestacji okazuje się właśnie humanistyka ekologiczna „,karmiąca się ideami symbiotycznych relacji, opartych na wzajemnych zależnościach wspólnot ludzkich i nie-ludzkich person"13. Inaczej mówiąc:

Jest to utopia, w której wyjaśniające proces historyczny teorie konfliktu zastępowane są teoriami współpracy, współbycia i kolaboracji; a dotychczas wszechpanujące pojęcie traumy jako podstawy tworzenia się jednostkowej i wspólnotowej tożsamości, zastępowane jest pojęciem empatii i zdolnego do adaptacji, rewitalizacji i autoregeneracji podmiotu ${ }^{14}$.

Jednak to właśnie dramatyczne historie zebrane w Czarnobylskiej modlitwie ukazują antyutopię, która $\mathrm{w}$ odwrócony sposób potwierdza rozpoznanie o niezbywalnej wspólnocie ludzkich i nie-ludzkich person. To odwrócenie narusza utopijny optymizm dążeń ekokrytycznych, choć potwierdza sedno ich przesłania.

W artykule poświęconym kulturze ukraińskiej po katastrofie, zatytułowanym Czarnobyl, nuklearna apokalipsa $i$ postmodernizm Tamara Hundorowa postawiła diagnozę, której ośrodkiem pozostaje przekonanie, iż „dyskurs czarnobylski pozostając dyskursem postkatastroficznym i posttraumatycznym, jest nie tylko środkiem komentowania współczesności i realnych wypadków, ale formuje nowe sposoby myślenia" ${ }^{15}$. Hundorowa stwierdziła, iż z jednej strony apokaliptyczne postrzeganie Czarnobyla „nakłada się na ogólne millenarystyczne, apokaliptyczne oczekiwania na granicy XXI wieku" ${ }^{16}$, z drugiej natomiast strony apokalipsa jądrowa, stając się ważną metaforą kulturową ${ }^{17}$, przyczyniła się do powstania fałszywej, bo ufundo-

\footnotetext{
12 E. Domańska, Humanistyka ekologiczna, „Teksty Drugie” 2013, nr 1/2, s. 31.

13 Tamże.

14 Tamże.

15 T. Hundorowa, Czarnobyl, nuklearna apokalipsa i postmodernizm, przeł. I. Boruszkowska, „Teksty Drugie" 2014, nr 6, 253.

16 Tamże, s. 257.

17 Hundorowa wskazuje, iż apokalipsa jądrowa, jako swoiste „laboratorium obrazów” łączy się z tak różnymi tematami jak: „progres technologiczny, rola intelektualistów w społeczeństwie, natura szaleństwa i narodziny nowego człowieka, postrzeganie Innego i miejsce monstrualności w kulturze, historia katastrofy i futurystyczne modele świata" [tamże, s. 259].
} 
wanej na przekonaniu o koniecznym nadejściu końca świata, idei porozumienia ponad podziałami narodowymi, rasowymi, płciowymi. Należałoby jednak zadać pytanie, czy rzeczywiście idea jest fałszywa jako oparta na błędnych przesłankach. Pesymistyczna wizja nieuchronnej apokalipsy jest przynajmniej tak samo prawdopodobna jak optymistyczna wizja wiecznego trwania ludzkiego gatunku.

Ukraińska badaczka w zakończeniu swojego tekstu przekonywała, iż w ramach "nurtu czarnobylskiego" wykształciły się szczególne sposoby przekazywania "nieprzedstawialnego", które można uznać za swoisty nakaz, by: „unikać bezpośredniego obrazowania i reprezentacji, odtwarzać negatywnie, pozwalać na to, aby coś oglądać, ale zabraniać zobaczyć; iść naprzód, powtarzając; sprawiać przyjemność powodując ból"18. Czarnobylska modlitwa białoruskiej pisarki stanowi przekroczenie konwencji właśnie ze względu na decyzję oddania głosu ofiarom - z ich bolesnych spowiedzi, z niezliczonych obrazów traumatycznych doświadczeń, czytelnik ma możliwość szczegółowego odtworzenia przestrzeni apokalipsy.

Każdą z trzech części książki kończy chór, choć głosy w nich zebrane nie komentują wydarzeń na wzór chóru z greckiej tragedii, lecz rozpadają się na pojedyncze skargi - nie stanowią homofonicznego, budowanego z dystansem przesłania, lecz polifoniczne zwielokrotnienie przekazu. W pierwszym z nich, Chórze żotnierzy, zamieszczono wypowiedź jednego z likwidatorów, który po powrocie do domu wyrzucił robocze ubranie, na swoje nieszczęście nie całe: „furażerkę podarowałem małemu synkowi. Bardzo prosił. Potem nie chciał jej zdejmować. Po dwóch latach postawiono mu diagnozę: rak mózgu..." [s. 85]. Jednym z głosów w Chórze ludowym, kończącym drugą część utworu jest wyznanie kobiety, która nie zgodziła się na aborcję, pomimo namów lekarzy, przewidujących nieszczęście, ponieważ ojciec dziecka był kierowcą wożącym piasek i beton na osłonę reaktora:

Oczekiwaliśmy pierworodnego. Mąż wolał chłopczyka, ja dziewczynkę. [...] Czytałam w książkach, że miłość wszystko zwycięża. Nawet śmierć. Dziecko urodziło się martwe. Nie miało dwóch paluszków. To była dziewczynka. Płakałam. No niechby przynajmniej miała wszystkie paluszki. Przecież to dziewczynka... [s. 179].

Ostatnią część książki zamyka Chór dzieci. Ich głosy to w istocie zapis rozpaczliwych prób zrozumienia świata, w którym przyszło im żyć, uporządkowania wiedzy o prawidłach egzystencji, szczególnie trudnych do pojęcia, kiedy żyje się w przestrzeni naznaczonej śmiercią - członków rodziny, dziad-

18 Tamże, s. 262. 
ków, rodziców, ale i rówieśników: rodzeństwa, kuzynów, kolegów. Umierające dzieci prosiły: „Kiedy umrę, nie chowajcie mnie na cmentarzu, bo ja się cmentarza boję, tam są tylko umarli i wrony. Pochowajcie mnie lepiej na polu..." [s. 268]. Inne „wybierały” śmierć zamiast zdegradowanej, kalekiej, pozbawionej realnych widoków na przyszłość egzystencji ${ }^{19}$.

W opowieściach czarnobylskich wysunięta została na plan pierwszy wiedza o tym, że śmiertelność, podatność na zranienie, okaleczenie, chorobę jest tym, co stanowi istotę ludzkiej kondycji, niezbywalną cechę ludzkiego gatunku, dzieloną z innymi istotami żywymi. Wiedza ta, osadzona w mających długą tradycję filozoficzno-intelektualnych poszukiwaniach, w Czarnobylskiej modlitwie zyskała dotkliwie dosłowny wymiar substancjalno-emocjonalny. Aleksijewicz stwierdza ironicznie: „Bohaterowie Czarnobyla mają jeden pomnik... Wykonany ludzkimi rękami sarkofag, w którym złożyli płomień nuklearny. Piramidę XX wieku” [s. 37]. „Pomnik” wraz z otaczającą go najsilniej napromieniowaną strefą to specyficzne nie-miejsce pamięci, które można postrzegać jako symbol całej skażonej przestrzeni. Autorka mówi wprost: „Sarkofag to nieboszczyk, który oddycha. Oddycha śmiercią" [s. 9].

Zniszczoną ziemię można $\mathrm{z}$ jednej strony uznać za ślad po kolejnej wieży Babel - następnym wyzwaniu rzuconym siłom wyższym. Można jednak z drugiej strony skupić uwagę na zaskakujących procesach odżywania tych terenów, ich samoczynnej regeneracji, ponownego zasiedlania nie tylko przez ludzi wracających do domów rodzinnych, ale i dzikie zwierzęta anektujące wolną przestrzeń. Jurij Andruchowycz w swoim Leksykonie miast intymnych opatrzonym ironicznym podtytułem Swobodny podręcznik do geopoetyki i kosmopolityki zamieścił rozdział sygnowany nie, jak inne, nazwą miasta, lecz X, 1970-1986, co wyjaśnił prosto - nazywając tak miasto Prypeć (nad rzeką Prypeć) wybrał symbolikę radioaktywnych promieni $X$ i zamkniętej strefy X jako znaku „zamordowanego miejsca”. Miasto zbudowane specjalnie dla pracowników elektrowni istniało tylko przez 16 lat - pozostało wyraźnym śladem klęski człowieka:

$\mathrm{X}$ to miasto nie tylko porzucone, ale też rozgrabione, miasto na wynos, miasto rozniesione. I stąd jego szczególna atrakcyjność. Już nie miasto, tylko ciało, zbiorowo gwałcone przez wciąż nowe watahy ratowników-kochanków ${ }^{20}$.

19 Relacja nastoletniego Borisa jest historią utraty przyjaciół: „Mój najlepszy przyjaciel miał na imię Andriej... Dwa razy go operowali, a potem wysłali do domu. Za pół roku mieli go operować po raz trzeci. Powiesił się na własnym pasku... W pustej klasie, kiedy wszyscy poszli na wuef. Lekarze zabronili mu biegać, skakać, a on był najlepszym piłkarzem w szkole. Przed..." [s. 268].

20 J. Andruchowycz, Leksykon miast intymnych. Swobodny podręcznik do geopoetyki i kosmopoliytki, przeł. K. Kotyńska, Wołowiec 2014, s. 466. 
Opisując wymarłą strefę, Andruchowycz wskazuje w niej jednak zastanawiające, zmutowane przejawy rozbuchanego życia - na przykład „sumy niepospolite", z radioaktywnych kanałów elektrowni, które "żyć będą wiecznie. I jak świadczą ich rozmiary $w$ dwudziestym piątym roku tego wiecznego życia po katastrofie, $w$ dodatku wiecznie będą rosnąć. I wyrosną z nich kiedyś wieczne dziwy lewiatany" ${ }^{21}$. Przyroda odrodziła się z niepokojącą intensywnością, pozostawiona sama sobie zdaje się zaświadczać o swej sile, choć drogi (i skutki) jej regeneracji pozostają nieprzewidywalne. Andruchowycz podkreślał, co prawda, zgodnie ze swymi inklinacjami do rozpoznawania zawikłanych historii miejsc, że to dzięki konfliktowi światowych systemów politycznych niewidzialna śmierć mogła zaistnieć jako temat w przestrzeni publicznej ${ }^{22}$. W obrazie Prypeci interesowała go jednak bardziej relacja człowieka z Naturą, jego klęska w wymiarze nie tyle społecznym, co gatunkowym.

Po Czarnobylu rzeczywistym przegranym musiał okazać się nie system państwowy czy ideologia postępu, ale człowiek pozbawiony dawnych złudzeń. Pisarz przytoczył słowa jednego z budowniczych elektrowni z filmu propagandowego sprzed katastrofy:

co najdziwniejsze żyjemy tu w takiej bliskości z przyrodą, jesteśmy jej częścią! Chcesz, kąp się w rzece, idź do lasu, wędruj wśród sosen, oddychaj, nazbieraj patelnię grzybów na kolację, wszystko tu mamy, tuż obok, jesteśmy w środku, w środowisku ${ }^{23}$.

Komentując je następnie stwierdził, iż po katastrofie szyderstwem wydawały się nie tylko te słowa, ale cały wbudowany w propagandę sukcesu „zwycięski dyskurs, w którym słowa «człowiek» i «przyroda» pisze się już wyłącznie wielkimi literami C i P, Człowiek i Przyroda, CzłowiekoPrzyroda, święto harmonii" 24. Antropocentryczny ogląd świata pozwalał człowiekowi karmić się wizjami odgórnie konstruowanej harmonii ze światem, możliwości panowania nad Naturą - okazały się one ostatecznie szkodliwą uzurpacją.

Antropocentryczne wizje "czynienia sobie ziemi poddaną" pozostają też biegunowym odwróceniem głównego założenia współczesnych historyków

21 Tamże, s. 465.

22 W ujęciu Andruchowycza: „A jednak dobrze, że istniał konflikt systemów. Dobrze, że Szwecja podniosła raban i wskazała na zagrożenie dla Polski. Dobrze, że Polska przestawała już być przyjacielem i coraz bardziej odwracała się w stronę Zachodu. Tym razem odwróciła się od radioaktywnej chmury - wstrzymała oddech i z obrzydzeniem zatkała nos. Dobrze, że Polska się przestraszyła i podchwyciła wołanie Szwecji" [s. 465].

23 Tamże, s. 463.

24 Tamże. 
ewolucji, które w ujęciu Christiana W. Simona brzmi: „Natura nie jest abstrakcją pozostającą poza sferą (lub w opozycji do) ludzkich działań, łączy się bowiem z problemami i osiągnięciami społeczeństw ludzkich - nie zaś populacji - wraz z ich gospodarkami" ${ }^{25}$. Suma konkretnych, wymiernych działań państw i korporacji prowadzi do zmian globalnych, niemożliwych do oddzielenia zarówno od funkcjonowania ludzi w teraźniejszości, jak i perspektyw ich dalszych dziejów. Przyjęcie takich założeń służy odsłonięciu w perspektywie historycznej, współczesnej i przyszłej - „ludzkiej” natury samej „Natury” 26.

Współcześni naukowcy wskazują na paradoks ewolucyjnego sukcesu ludzkiego gatunku. Maciej Trojan, badacz nauk przyrodniczych, przekonywał:

Nasz sukces ewolucyjny - że się tak rozleźliśmy po świecie, że jesteśmy w stanie wszystko przekształcić - jest też naszą zgubą. [...] Zużywamy o połowę więcej niż się odtwarza. Tylko załamanie ludzkiej populacji jest w stanie to zatrzymać ${ }^{27}$.

Zdaniem Trojana katastrofa jest nieunikniona, bowiem nigdy dotąd nie zużywaliśmy zasobów planety tak szybko, żeby nie mogła się zregenerować. Mimo zwielokrotniania i nagłaśniania ostrzeżeń $w$ ostatnich dekadach, przestrogi naukowców wieszczących prawdopodobną zagładę ludzkości nie skutkują wprowadzeniem skutecznych środków zapobiegawczych ani w skali lokalnej, ani tym bardziej globalnej. Temat zagłady został natomiast przejęty przez kulturę, zwłaszcza masową, jako atrakcyjny motyw cieszących się popularnością tekstów, komiksów, filmów katastroficznych ${ }^{28}$

${ }^{25}$ Ch. W. Simon, "Historia Ewolucyjna”, przeł. P. Ambroży-Lis, w: Teoria wiedzy o przeszłości na tle wspótczesnej humanistyki, red. E. Domańska, Poznań 2010, s. 612. Projekt „historii ewolucyjnej" zakładający sprzężenie wysiłków badaczy tradycyjnej historii naturalnej, biologii ewolucyjnej oraz historyzujących nauk społecznych ma służyć badaniu zjawisk w ich wzajemnych interakcjach, konstruowaniu „przestrzeni relacyjnych”, tworzeniu analiz na wyższym stopniu złożoności.

26 Tamże, s. 627.

27 M. Trojan, Wiemy, że coś wiemy, „Polityka” 2016, nr 24, s. 70. Badacz zajmujący się psychologią porównawczą i etologią poznawczą tak rozwinął wizję przyszłości naszego globu: „zasoby rosną liniowo, a ludzie przyrastają geometrycznie, musi się więc to skończyć walką o byt. [...] Natura w końcu da sobie radę, tylko my w tym czasie wybijemy mnóstwo gatunków, w końcu sami pomrzemy, bo nie będzie co jeść, zasobów będzie za mało dla wszystkich. Wtedy nastąpi kolejny skok ewolucyjny" [s. 70].

28 Miasto Prypeć stało się "dogodnym” planem filmowym piątej odsłony popularnej serii filmów sensacyjnych, w Polsce noszącej tytuł Szklana pułapka (A Good Day to Die Hard, reż. J. Moore, USA 2013). 
- utwory tego typu z jednej strony banalizują wizje końca świata, z drugiej jednak rozbudzają $\mathrm{w}$ odbiorze masowym świadomość istnienia realnych zagrożeń dla całej ludzkości i jej przyszłego trwania. Procesy ekologicznego uwrażliwiania jednostek i społeczeństw przebiegają jednak w dość powolnym tempie.

Aleksijewicz ukazuje w epilogu współczesny status miejsca katastrofy, dziś Mekki dla tych, którzy pragną połączyć wyjazd wakacyjny z „dotknięciem historii". Czeka ich wiele atrakcji:

No a na koniec podróży miłośników turystyki ekstremalnej czeka piknik z obiadem z ekologicznie czystych potraw. Do tego czerwone wino... i rosyjska wódka. Zapewnia się nas, że przez cały dzień spędzony w strefie otrzymamy dawkę promieniowania mniejszą niż podczas badania rentgenowskiego. Nie zaleca się jednak kąpieli, jedzenia złowionych ryb i upolowanej zwierzyny, zbierania jagód i grzybów, ani też smażenia ich nad ogniskiem. Nawet wręczania paniom polnych kwiatów [s. 281-282].

Można zatem odegrać rolę zdobywcy i sfotografować się na tle wymarłego miasta, a choć w tym właśnie miejscu nie można już zachowywać złudzeń o panowaniu człowieka nad światem natury, to zalecana przez organizatorów ostrożność zdaje się w odbiorze wielu turystów raczej wzmacniać dreszcz emocji, niż skłaniać do zastanowienia. Dla traktujących historię Czarnobyla podobnie jak Aleksijewicz, jako przestrogę na przyszłość, przestrzeń wokół reaktora pozostanie strefą pamięci o ofiarach, dla innych funkcjonować będzie jako jeden z przystanków na trasach „turystyki ekstremalnej”.

Lektura Czarnobylskiej modlitwy skłania do postawienia pytań dotyczących funkcjonowania "tematu czarnobylskiego", spychanego na marginesy kultury, ograniczanego do jej lokalnych lub popularnych wymiarów, istniejącego wciąż na obrzeżach zbiorowej (gatunkowej) pamięci. Waga problemu prowadzić może także do namysłu nad zadaniami dzisiejszej humanistyki. W artykule Animal studies, dyscyplinarność $i$ post(humanizm) Cary Wolfe włączył się jednoznacznie w nurt krytycznej refleksji nad pozornymi (czy też pozorowanymi) współczesnymi metodami rozszerzania zasięgu humanistyki i jej pól badawczych. Za szczególnie niekorzystne zjawisko uznał - poddawane już wcześniej wielokrotnie nieufnemu oglądowi - tworzenie kolejnych subdyscyplin, powstających wedle sprawdzonego schematu "studia nad (wstaw brakujące określenie)" ${ }^{29}$. Ujednolicająca moc wzorca sugeruje,

${ }^{29}$ C. Wolfe, Animal studies, dyscyplinarność i post(humanizm), przeł. K. Krasuska, „Teksty Drugie" 2013, nr 1/2, s. 149. 
iż różne problemy, formacje i obszary badawcze stają się z jednej strony równoważne, z drugiej zaś osobne, niejako równoległe.

Posthumanizm w szerszym ujęciu byłby więc nie tyle, czy nie tylko manifestacją uwrażliwienia na różnicę oraz empatii wobec rozszerzonej kategorii Innego, ile językiem pozwalającym na poszerzenie badawczej samoświadomości, uznanie i zrozumienie wszelkich dyskursywnych ograniczeń tworzonych teorii (fragmentarycznych projektów metodologicznych). Wolfe przekonywał:

posthumanizm można więc zdefiniować dość precyzyjnie jako uznanie wymogu, by wszystkie dyskursy bądź procedury krytyczne zdawały sprawę z konstytutywnej (oraz konstytutywnie paradoksalnej) natury własnych rozróżnień, form i procedur - oraz, by stosowały wówczas strategie odmienne od form refleksji czy introspekcji wiązanych z krytycznym podmiotem humanizmu ${ }^{30}$.

Tak pojmowane założenia posthumanizmu pozwalają dokładniej zrozumieć czarnobylską apokalipsę, bo była ona wyrazistym dowodem na uzurpacyjny charakter założeń antropocentryzmu. Uznać także należy, że punkt wyjścia, czyli "podstawa” badań staje się w takim ujęciu „nie-miejscem”, „formą różnicy", co pozwala otwierać się na inność innego ze względu na same warunki poznania. Przyjęcie perspektywy uznającej wielość ograniczeń, powiązań i uwarunkowań ludzkiego bytowania w świecie (tak na płaszczyźnie egzystencjalnej, jak i epistemologicznej) mogłoby doprowadzić do upowszechnienia idei - wznoszącego się ponad wszelkie różnice - wspólnotowego przymierza, tworzonego w imię „odpowiedzialności za przyszłe pokolenia".

Opowieści z Czarnobylskiej modlitwy uświadamiają w bardziej wyrazisty niż inne teksty sposób, niemożność przekazywania doświadczeń. Otwierają jednak na cudze (także nie-ludzkie) przeżycia, a zarazem umożliwiają tworzenie uniwersalnych diagnoz. Sytuowane na przecięciu dyskursów posthistorycznych i posthumanistycznych narracje z czasu czarnobylskiego ekocydu pozwalają ujrzeć i pojąć postantropocentryczną wizję człowieka oraz odkryć wcześniej pomijane aspekty jego relacji z przestrzenią, Naturą, Historią.

30 Tamże, s. 149. 


\section{Ecocide Reconstructed - Past and Future in Svetlana Alexievich's Chronicle}

\section{Summary}

Drawing from ecocritical perspective and broader post-humanist framework, the author interprets Svetlana Alexievich's book, Chernobyl Prayer. Both the analysis of recorded oral stories and narrative strategies of selection, composition and style invite post-humanist approach. At the same time, the stories of Chernobyl nuclear disaster and the ensuing ecocide denounce anthropocentric humanism.

Keywords: ecocriticism, ecocide, post-humanism, Svetlana Alexievich, Chernobyl 